\author{
Military Technical College \\ Kobry El-Kobbah, \\ Cairo, Egypt
}

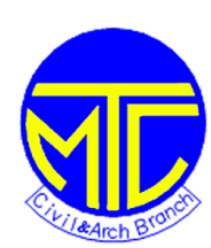

\section{$10^{\text {th }}$ International Conference on Civil and Architecture Engineering}

\section{ICCAE-10-2014}

\title{
Consultant Offices Selection using the Analytic Hierarchy Process
}

\author{
Y. Alamiri ${ }^{*}$, S. Mahfouz ${ }^{\ddagger}$, N. Amer ${ }^{\dagger}$
}

\begin{abstract}
Consulting offices selection is an important step in the success of a construction project. Selecting consultant offices in the Libya is often done by the criterion of lowest price. This leads to a lack of innovation and a loss of quality in the construction industry.

In this paper, the multi-criteria decision-making (MCDM) is suggests to be utilized for consultant offices selection. The analytic hierarchy process (AHP) has been used as a tool for MCDM. Here, the used criteria are those previously concluded from a former study. These criteria are human capabilities, office experience, previous performance level, assurance and quality control, office equipment, administrative system, training and development.

In the current study, two questionnaires have been designed. The first questionnaire is designed to determine the weights of relative importance of each criteria (main and sub-criteria). The answers to the questionnaire are analyzed using the Expert Choice program. The second questionnaire is designed to calculate the average rate of certain criteria. The weights of relative importance for each main and sub-criteria are used to assess a consulting office for both of design and supervision stages. Finally, an administrative buildings project is assumed and it is required to select an office out of four offices (A, $\mathrm{B}, \mathrm{C}$, and D) using the proposed methodology.
\end{abstract}

\section{Keywords}

Consulting offices, Selection Criteria, Multi Criteria Decision Making, and Analytical Hierarchy Process (AHP) 


\section{Nomenclature}

$\begin{array}{cl}\text { AHP } & \text { Analytical Hierarchy Process } \\ \text { A/E } & \text { Architectural Engaging } \\ \text { CCSM } & \text { Consultant Conceptual Selection Model } \\ \text { MCDM } & \text { Multi-Criteria Decision-Making } \\ \text { ANP } & \text { Analytic Network Process } \\ \text { CR } & \text { Consistency Ratio } \\ \text { W } & \text { Relative weights for the main criteria } \\ \text { GSMC } & \text { Geological Survey and Mining Company } \\ \text { G } & \text { General weight for the criterion } \\ \text { L } & \text { Local weight for the criterion }\end{array}$

\section{Introduction}

The Analytic Hierarchy Process (AHP) is a multi-criteria decision-making approach and was developed by Thomas [1]. The AHP has attracted the interest of many researchers mainly due to the useful mathematical properties of the method and the fact that the required input data are rather easy to obtain. The AHP facilitates the decision process by considering the decision in the context of a hierarchy, with the goal at the top, criteria at the second level, sub-criteria at various lower levels, and alternatives at the bottom of the hierarchy. The decision-maker makes pair-wise comparisons of elements at each level of the hierarchy. Each entity at a particular hierarchy level is compared with each other entity at that level, in order to determine which is preferred to, or more important than, the other. Each pair-wise comparison (that is, comparisons of the various criteria, comparisons of the various sub-criteria, and comparisons of the various alternatives) is based on a nine-item verbal/numerical judgment scale. These comparisons are using to obtain the weights of importance of the decision criteria. The values of the pair-wise comparisons in the AHP are determined according to intensity of importance. Mubarak and Al-Besher, [2] discussed factors participating in making $\mathrm{A} / \mathrm{E}$ selection process for the public sector engaging consultants (A/E) for professional services. Thirty public organizations and thirty consultants were surveyed to identify the major selection criteria of A/E based on the AHP theory concept and a software program Expert Choice. The Authors focuses on personal experiences, qualifications and previous activities of individual engineers. Cheng, et. al [3] studied the best selection of architectural consultant in Hong Kong by conducting a questionnaire survey. This research identified the common criteria for selection the relative importance using AHP. Survey data from projects with similar characteristics was used to compute the criteria weights. Multi-criteria models for 7 out of 27 categories of project were built with reference to the computed weights derived from survey. Other authors have been studied the best selection of contractor in different countries, among them, Meghalkumar [4] suggested AHP technique for contractor selection problem in Indian context. Based on multi criteria decision making process, the data collected are used to create a hierarchical model for contractor selection. Eddie and Heng [5] suggested the multi-criteria decision-making (MCDM) to be a viable method for contractor selection. The AHP has been used as a tool for MCDM. However, AHP can only be employed in hierarchical decision models. For complicated decision problems, the analytic network process (ANP) is highly recommended since ANP allows interdependent influences specified in the model. An example is demonstrated to illustrate how this method is conducted, including the formation of super matrix and the limit matrix. Jaskowski, et. al [6] suggested the application of fuzzy AHP method to the process of decision making for selection of contractors. The assessment based on criteria related with a bidder's technical and economic 
in the prequalification stage in restricted tendering procedures. The results show that the proposed fuzzy AHP method is superior to the traditional AHP in terms of improved quality of criteria prioritization. It can be concluded that the wide use of AHP in different applications would imply its potential acceptability to practitioners as well as researchers. Furthermore, there is no research achieved for the selection of consulting offices.

The current paper presents the application steps of the AHP for the consultant offices selection. Questionnaire number (1) is designed according to the AHP at which bilateral comparisons between the main and sub-criteria are presented. The questionnaire is then spreaded over (30) expert engineers. The collected information are then analyzed and the arithmetic means are calculated. The questionnaire results are also used to determine weights of the relative importance of each criterion using Expert Choice program. Questionnaire number (2) is designed to calculate the average rate of certain criteria. The questionnaire is spreaded over (10) engineers with experience in the selection of consulting offices. The weights of relative importance for each main and sub-criteria are used to assess a consulting office for both of design and supervision stages. Finally, an administrative buildings project is assumed and the best office out of four offices (A, B, C, and D) is determined.

\section{Determination of the weights of relative importance}

AHP uses hierarchic or network structures to represent a decision problem and then develops priorities for the alternatives based on the decision-makers judgments throughout the system. The end product of the process is a prioritized ranking of the alternatives available to the decision-makers. The decision-makers must make judgments about the relative importance of each objective in paired comparison with each of the other objectives. They also must judge the relative merits of the alternatives with respect to each of the objectives. This is called relative measurement as opposed to absolute measurement, such as arbitrarily assigning a priority to each of the objectives, or stating that an alternative is high, moderate, or low and then arbitrarily assigning priorities to high, moderate, and low. The weights of relative importance to the criteria are determined using Expert Choice. The relative importance of each main criteria and sub-criteria shall be determined. Also, the relative preference of each alternative to each criterion is calculated using a process of pair-wise comparisons [7].

The bilateral comparisons between the criteria are represented numerically, according to Saaty's fundamental verbal scale [1].

In the current study, questionnaire, see Appendix (A), is designed to conduct bilateral comparisons between the criteria and to determine the relative important of each criterion in the selection of consulting offices. This questionnaire is spreaded over (30) expert engineers see Appendix (B). After that, the collected information are analyzed and the arithmetic mean for each criterion is calculated. Here, (170) comparisons, between two criteria, are achieved. The values of the comparisons in the AHP are determined according to the scale introduced by Saaty [1]. According to this scale, the available values for the pair-wise comparisons are members of the set: $\{9,8,7,6,5,4,3,2$, and 1$\}$, are as follows: (9) means extreme importance, (7) implies very strong importance, (5) mean strong importance, (3) equals moderate importance, (1) means equal importance. The values (2), (4), (6) and (8) are used when compromise is needed. The arithmetic means are then used as input data to the expert choice program to calculate the weight of relative importance of each criterion, see Appendix (C). 
Figure (1) shows a pair-wise verbal judgment expressing, that human capabilities equal importance with office experience. The marked numbers indicate that the criterion in the cell row is more important than the criterion in the cell column. Figure (2) shows the descending order of main criteria priorities. The Expert Choice program can also be used to calculate the Consistency Ratio (CR), (i.e. inconsistency index) in the data entered to make sure that it will not exceed (10\%) according to the analytic hierarchy process. The inconsistency index is not relevant if it is larger than $10 \%$, in which case the judgments should be reviewed. Reasons for a high inconsistency ratio may include lack of information, lack of concentration and real world inconsistencies.

\begin{tabular}{|c|c|c|c|c|c|c|c|}
\hline \multicolumn{8}{|c|}{ Verbal scale } \\
\hline \multicolumn{7}{|c|}{ Human capabilities } & \multirow{3}{*}{ 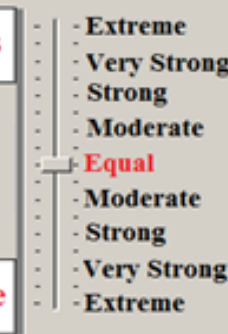 } \\
\hline \multicolumn{7}{|c|}{$\begin{array}{l}\text { Compare the relative importance with respect to: } \\
\text { The main criteria for the evaluation and selection of the consulting offices in libya }\end{array}$} & \\
\hline & & & & & & ffice experience & \\
\hline & Human cap & Office exp & revious pe & Quality cor & Office eq & Training and dev & Administrative sy \\
\hline Human capabilities & & 1.02 & 2.07 & 1.4 & 4.21 & 2.15 & 2.14 \\
\hline Office experience & & & 1.07 & 1.1 & 3.87 & 1.24 & 1.66 \\
\hline Prerious performance lerel & & & & 1.12 & 2.95 & 1.24 & 1.61 \\
\hline Quality control & & & & & 2.96 & 1.47 & 1.59 \\
\hline Office equipment & & & & & & 2.74 & 2.19 \\
\hline Training and derelopment & & & & & & & 1.64 \\
\hline Administratire șystem & & & & & & & \\
\hline
\end{tabular}

Fig. (1) Assigning verbal judgement for comparisons

Priorities with respect to:The Main Criteria for The Selection of The Consulting Offices in Construction projects

Human Capabilities

Office Experience

Assurance and Quality Control

Level of Performance Previous

Training \& Development

Administrative System

Office Equipment

Inconsistency $\mathbf{= 0 . 0 1}$

with 0 missing judgments.

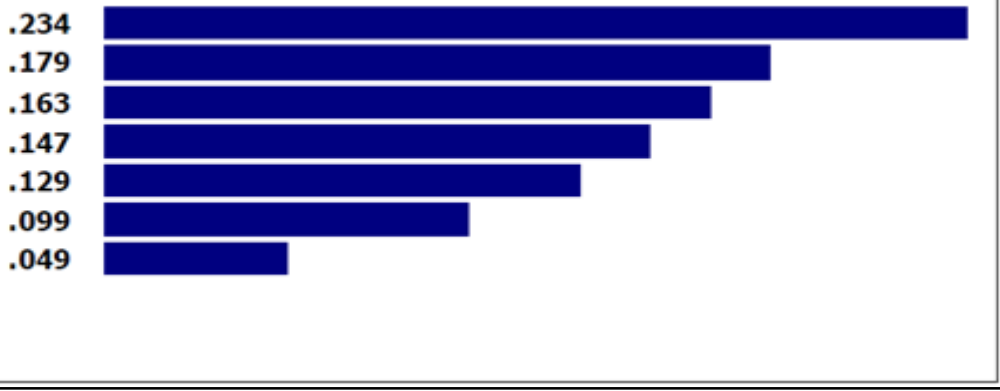

Fig. (2) Priorities resulting of the main criteria

\section{Sensitivity Analysis}

The last step of the decision process is the sensitivity analysis, where the input data are slightly modified in order to observe the impact on the overall results. If the ranking does not change, the results are said to be robust. Sensitivity analysis examines the sensitivity of the results to changes in the priorities of the criteria. Expert Choice allows different interaction graphical interface sensitivity analyses techniques. (1) Performance, (2) Dynamic, (3) Gradient, (4) two-dimensional plot, and (5) differences and each of them provide a different viewpoint to sensitivity analysis. Here, the user can easily manipulate criterion priorities and 
immediately see the impact of the change over the result [8], [9]. For the current study the application of the dynamic sensitivity for the criteria Figure (3), shows the arrangement of all criteria according the relative importance in the design stage and supervision stage.

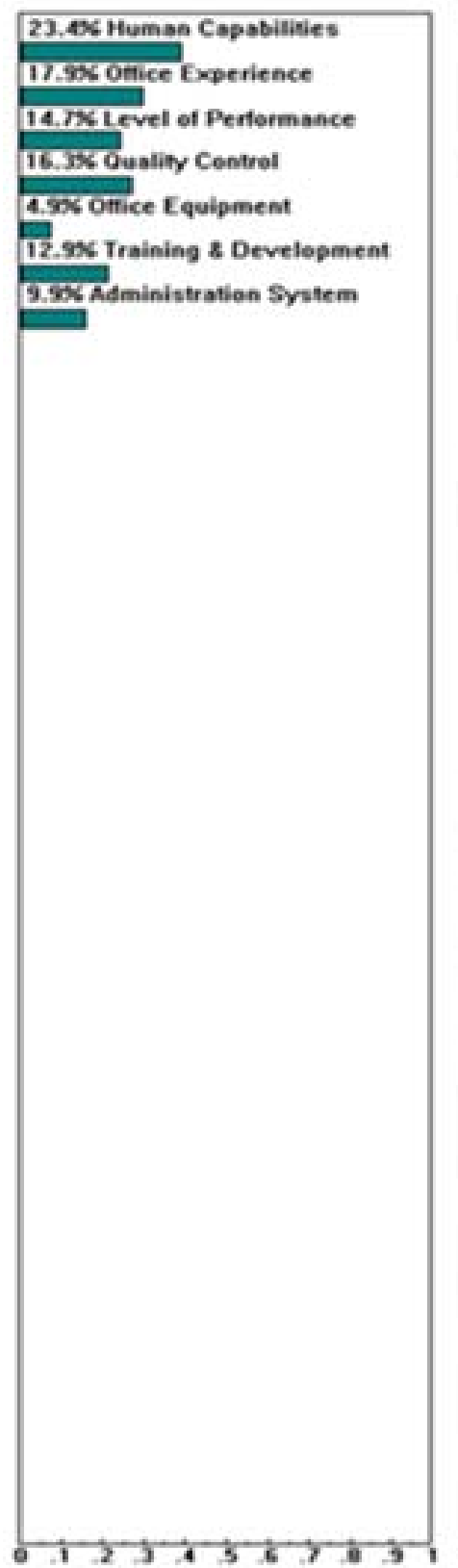

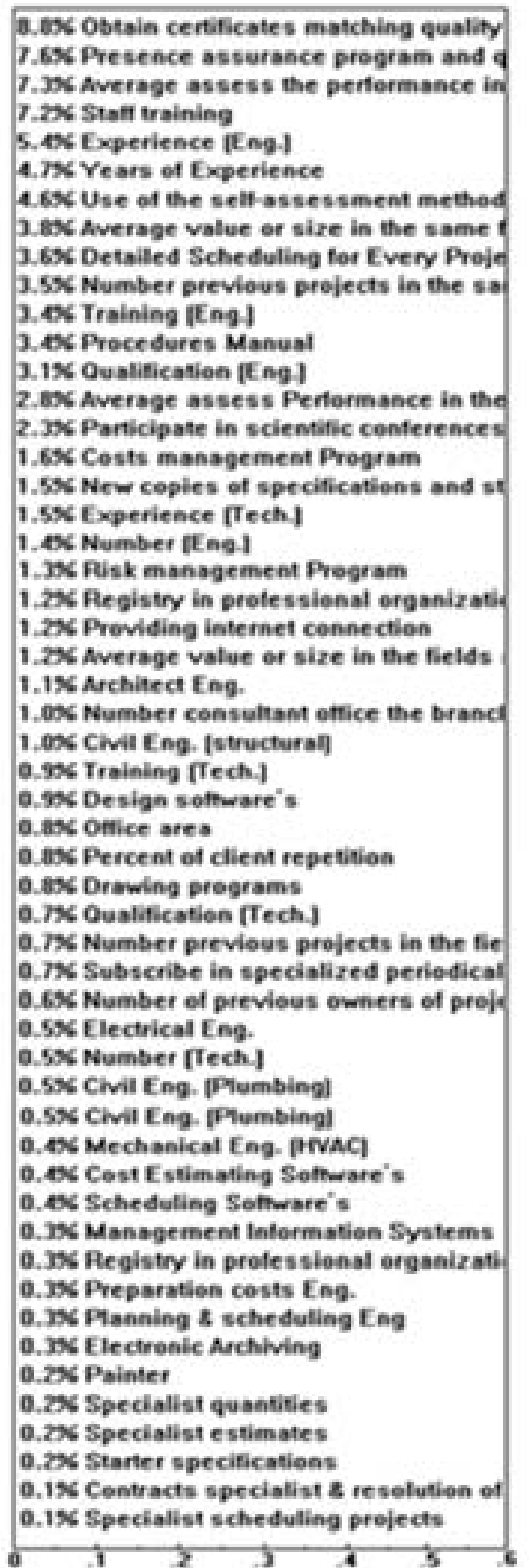

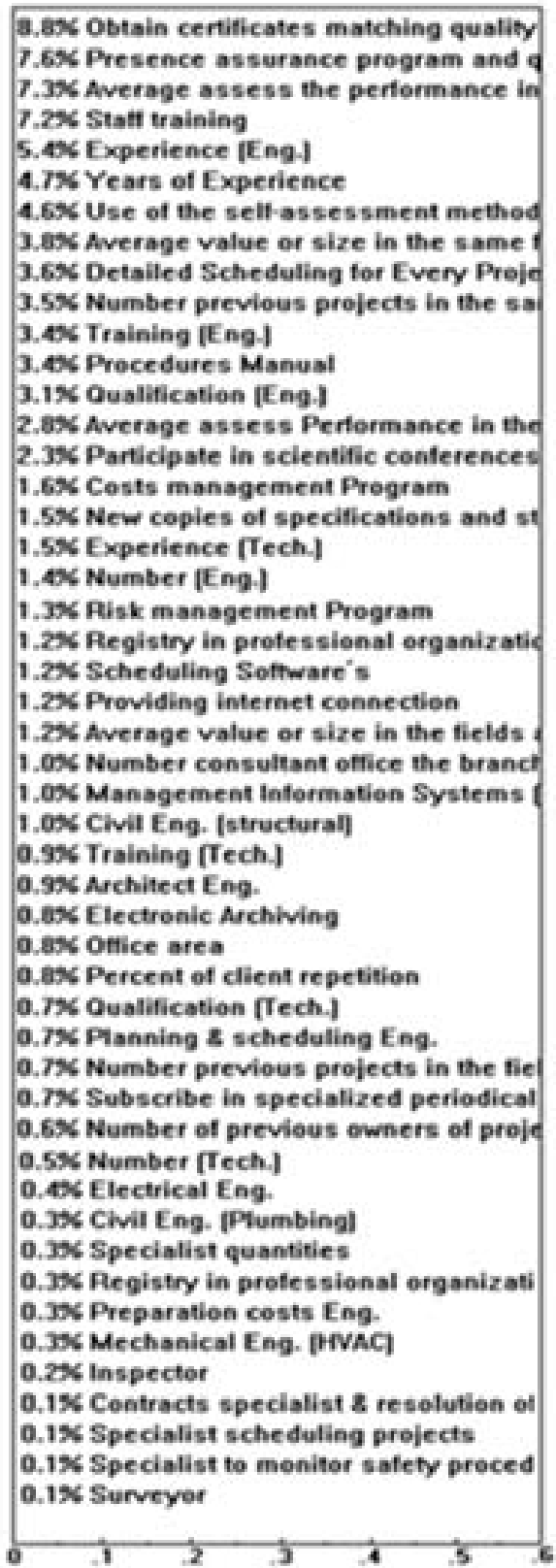

3.83 Obtain certificates matching quality GXrescece assurance program and 1.206 Statt training

Experience fEng. 3.65 Detailed Scheduling for Every Proi $3.5 \times$ Number previous projects in the sa

.656 Costs managemeat Prograen

New copies of specitications and st

Exprience ITech.

1.20 Scheduling Software"s

1.20 Providing internet cennectien

OAK Number consultar

1.0\% Management Iaformation Systems

a.as Percent of client repetition

Qualification [Tech.]

X Planning 8 scheduling Eng.

$0.5 \%$ Number [Tech.

0.456 Electrical Eng.

0.306 Civil Eng. [Plumbing

Registry in profes sitonal erganizati

0.226 Inspector

$0.1 \%$ Specialist to monitor safety proced

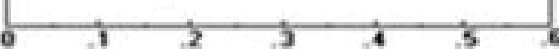

Fig. (3) Dynamic sensitivity: goal: selection of the consulting offices in

(Design stage and supervision stage)

\section{The average rate of certain criteria}

To calculate the average rate of certain criteria, the type of project is determined (i.e. administrative buildings in the government institutions). Also, the task for the consulting office is determined (design stage and supervision stage) and the weights of relative importance for criteria (main and sub-criteria) are determined. A questionnaire number (2) is designed to calculate the average rate of certain criteria, see Appendix (D). The questionnaire is spreaded over engineers with experience in the selection of consulting offices. Table (1) shows the results of the average rate of certain criteria.

\section{Table (1) Average rate of certain criteria}




\begin{tabular}{|c|c|c|c|}
\hline No. & The criteria & Unit & Average \\
\hline 1. & Number of Engineers and architects. & number & 31 \\
\hline 2. & Average years the experience to engineers and architects. & year & 13 \\
\hline 3. & Average number of months training for the engineers in the office & month & 10.5 \\
\hline 4. & Ratio of the certificate holders (master) from engineers & $\%$ & 80.3 \\
\hline 5. & Ratio of the certificate holder (bachelor) from engineers & $\%$ & 69.3 \\
\hline 6. & Percentage of registered engineers in professional organizations. & $\%$ & 45 \\
\hline 7. & Number of assistants technicians & number & 34 \\
\hline 8. & Average years of experience technician’s assistants & year & 13.7 \\
\hline 9. & Average number of months training for technicians in the office & month & 13.7 \\
\hline 10. & Rate of the certificate holders (diploma) from technician’s & $\%$ & 62.9 \\
\hline 11. & Percentage of registered technicians in professional organizations & $\%$ & 34.7 \\
\hline 12. & Number of years' experience for the office & year & 15 \\
\hline 13. & Number the previous projects in the same field and the task & number & 25 \\
\hline 14. & The average value of previous projects in the same field and the same task & LY D & 353,725 \\
\hline 15. & Number the previous projects in the other fields and the tasks & number & 4 \\
\hline 16. & The average value of previous projects in the other fields and the tasks & LY D & 280,225 \\
\hline 17. & The no. of previous owners of projects who have been dealing with them & number & 13 \\
\hline 18. & Percentage of client repetition who have been dealing with them & $\%$ & 40 \\
\hline 19. & Number of previous projects in the same field and the task & number & 65 \\
\hline 20. & Number of previous projects in the fields and other & number & 75 \\
\hline 21. & Average of office area & $\mathrm{m}^{2}$ & 380 \\
\hline 22. & Average of number consultant office the branches & number & 3.2 \\
\hline 23. & Average number of months the training provided for staff & month & 1.4 \\
\hline 24. & Number posts in scientific conferences and seminars & number & 6 \\
\hline
\end{tabular}

\section{Evaluation methodology}

The weights of relative importance for each main and sub-criteria are used to assess a consulting office using the following equations for both of design and supervision stages.

$$
\begin{gathered}
E_{H C}{ }^{d}=\sum_{i=1}^{6} E_{i}^{d} W_{i}+\sum_{j=1}^{6} E_{j}^{d} W_{j} \\
E_{H C}{ }^{s}=\sum_{i=1}^{6} E_{i}^{s} W_{i}+\sum_{j=1}^{6} E_{j}^{s} W_{j} \\
E_{O E}=\sum_{o Q=1}^{4} E_{\text {oe }} W_{\mathrm{oe}} \\
E_{P P}=\sum_{p p=1}^{3} E_{p p} W_{P P} \\
E_{Q C}=\sum_{q c=1}^{2} E_{q c} W_{q c} \\
E_{O Q}{ }^{d}=\sum_{o q=1}^{3} E_{o q}^{d} W_{o q}
\end{gathered}
$$




$$
\begin{gathered}
E_{O Q}{ }^{s}=\sum_{o q=1}^{3} E_{o q}^{s} W_{o q} \\
E_{T D}=\sum_{t d=1}^{3} E_{t d} W_{t d} \\
E_{A S}=\sum_{a s=1}^{4} E_{a s} W_{a s}
\end{gathered}
$$

$$
\begin{gathered}
\mathrm{FED}=E_{H C}{ }^{d} \mathrm{~W}_{\mathrm{HC}}+E_{O E} \mathrm{~W}_{\mathrm{OE}}+E_{P P} \mathrm{~W}_{\mathrm{PP}}+E_{Q C} \mathrm{~W}_{\mathrm{QC}}+E_{O Q}{ }^{d} W_{O Q}+E_{T D} W_{T D}+E_{A S} W_{A S} \\
\mathrm{FES}=E_{H C}{ }^{s} \mathrm{~W}_{\mathrm{HC}}+E_{O E} \mathrm{~W}_{\mathrm{OE}}+E_{P P} \mathrm{~W}_{\mathrm{PP}}+E_{Q C} \mathrm{~W}_{\mathrm{QC}}+E_{O Q}{ }^{s} W_{O Q}+E_{T D} W_{T D}+E_{A S} W_{A S}
\end{gathered}
$$

Where:

$E_{H C}{ }^{d} \quad$ The human capabilities criterion evaluation in design stage

$E_{i}^{d} \quad$ Evaluation of the sub-criteria (engineers criterion) in design stage

$E_{j}^{d} \quad$ Evaluation of the sub-criteria (technicians criterion) in design stage

$E_{i}^{s} \quad$ Evaluation of the sub-criteria (engineers criterion) in supervision stage

$E_{j}^{S} \quad$ Evaluation of the sub-criteria (technicians criterion) in supervision stage

$E_{H C} s \quad$ The human capabilities criterion evaluation in supervision stage

$W_{i} \quad$ Weight of the engineers criterion

$W_{j} \quad$ Weight of the technicians criterion

$E_{O E} \quad$ The office experience criterion evaluation

$E_{\text {oB }} \quad$ Evaluation of the sub-criteria (office experience criterion)

$W_{o \text { o }} \quad$ Weight of the sub-criteria (office experience criterion)

$E_{P P} \quad$ The previous performance level criterion evaluation

$E_{p p} \quad$ Evaluation of the sub-criteria ( previous performance level criterion)

$W_{p p} \quad$ Weight of the sub-criteria ( previous performance level criterion)

$E_{Q C} \quad$ The quality control criterion evaluation

$E_{\text {qc }} \quad$ Evaluation of the sub-criteria ( quality control criterion )

$W_{q c} \quad$ Weight of the sub-criteria ( quality control criterion )

$E_{O Q}{ }^{d} \quad$ The office equipment criterion evaluation in design stage

$E_{o q}^{d} \quad$ Evaluation of the sub-criteria (office equipment) in design stage

$E_{O Q}{ }^{s} \quad$ The office equipment criterion evaluation in supervision stage

$E_{\text {oq }}^{s} \quad$ Evaluation of the sub-criteria (office equipment) in supervision stage

$W_{\text {oq }} \quad$ Weight of the sub-criteria (office equipment criterion )

$E_{T D} \quad$ The training and development criterion evaluation

$E_{t d} \quad$ Evaluation of the sub-criteria (training and development)

$W_{t d} \quad$ Weight of the sub-criteria ( training and development criterion )

$E_{\text {AS }} \quad$ The administrative system criterion evaluation

$E_{a s} \quad$ Evaluation of the sub-criteria (administrative system )

$W_{a s} \quad$ Weight of the sub-criteria (administrative system criterion )

$W_{\text {HC }} \quad$ Weight of the human capabilities criterion

$W_{\mathrm{OE}} \quad$ Weight of the office experience criterion 


$\begin{array}{ll}W_{\mathrm{Pp}} & \text { Weight of the previous performance level criterion } \\ W_{\mathrm{QC}} & \text { Weight of the quality control criterion } \\ W_{\mathrm{OQ}} & \text { Weight of the office equipment criterion } \\ W_{\mathrm{TD}} & \text { Weight of the training and development criterion } \\ W_{\mathrm{AS}} & \text { Weight of the administrative system criterion } \\ \text { FED } & \text { Final evaluation in design stage } \\ \text { FES } & \text { Final evaluation in supervision stage }\end{array}$

Figure (4) illustrates the evaluation process for consultant office in design and supervision stages.

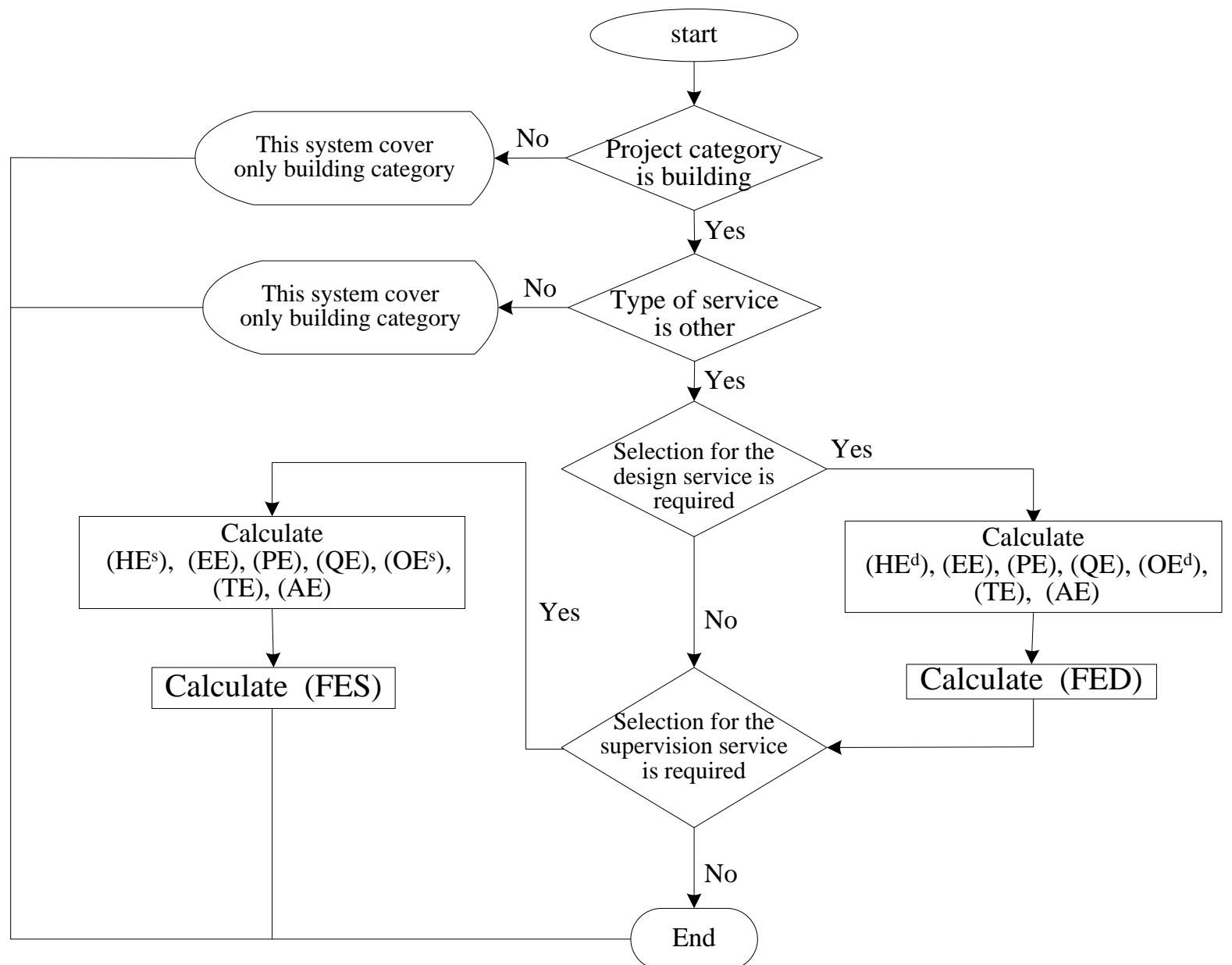

Fig. (4) The flowchart for the evaluation for consultant office

\section{Application for selecting the best consultant office: case study}

In this section, an administrative buildings project is assumed and it is required to select an office out of four offices (A, B, C, and D). Here, different information's about the four offices are gathered. These information are listed in Appendix (E). These information's are then analyzed using the techniques presented in the previous section. The final evaluation for each office is calculated and the results are shown in Table (2). 
Table (2) Summary of the results

\begin{tabular}{|c|c|c|c|c|c|c|c|c|}
\hline \multirow{3}{*}{ The criteria } & \multicolumn{8}{|c|}{ The evaluation for the consultant office } \\
\hline & \multicolumn{2}{|c|}{ office C } & \multicolumn{2}{|c|}{ office A } & \multicolumn{2}{|c|}{ office D } & \multicolumn{2}{|c|}{ office B } \\
\hline & Design & Supervision & Design & Supervision & Design & Supervision & Design & Supervision \\
\hline Human capabilities & 23.35 & 23.4 & 18.56 & 18.56 & 20.62 & 20.62 & 15.6 & 15.74 \\
\hline Office experience & 18.79 & 18.79 & 17.67 & 17.67 & 17.88 & 17.88 & 19.68 & 19.68 \\
\hline Previous performance level & 14.53 & 14.53 & 14.26 & 14.26 & 14.68 & 14.68 & 14.3 & 14.3 \\
\hline Quality control & 16.4 & 16.4 & 15.3 & 15.3 & 12.6 & 12.6 & 14.88 & 14.88 \\
\hline Office equipment & 4.66 & 4.32 & 4.73 & 4.73 & 5.21 & 4.31 & 5.21 & 4.31 \\
\hline Training and development & 12.56 & 12.56 & 13.01 & 13.01 & 11.06 & 11.06 & 10.62 & 10.62 \\
\hline Administrative system & 9.23 & 9.23 & 8.02 & 8.02 & 6.24 & 6.24 & 7.6 & 7.6 \\
\hline Final evaluation & 99.52 & 99.23 & 91.55 & 91.55 & $88.29 \%$ & $87.39 \%$ & $87.89 \%$ & 87.13 \\
\hline
\end{tabular}




\section{Conclusions}

The main conclusions may be drawn from this paper as follows:

[1] Scientific methodology of the selection on consulting offices based on (AHP) can be successfully applied to calculate the weights of the selection criteria through bilateral comparison between criteria in Libya.

[2] For the governmental construction projects in Libya, the weights of the relative importance of the main criteria that should be used in classification and the selection of consulting offices are: human capabilities (23.4\%), office experience (17.9), assurance and quality control (16.3), performance previous level (14.7\%), training and development (12.9\%), administrative system (9.9\%), office equipment (4.9\%).

[3] Application of the classification criteria to consulting offices allows to choose the best office for the design and supervision stages. The application shows the potential of the developed criteria for the selection of the best consultant office.

\section{References}

[1] Thomas L. S., Fundamentals of Decision Making and Priority Theory with the Analytic Hierarchy Process, 2006

[2] Mubarak Far. SA. Al-Besher, A conceptual model for a/e consultant selection (CCSM) in Saudi Arabia, 1998

[3] Cheung, Franco K.T. \& Kuen, Judy L.F. \& Skitmore, R.M., Multi-criteria evaluation model for selection of architectural consultants, 2002

[4] Meghalkumar I Zala, an Approach of Contractor Selection by Analytical Hierarchy Process, Nagar Gujarat India, 2011

[5] Eddie W. l. Cheng \& Heng Li, Contractor selection using the analytic network process, The Hong Kong Polytechnic University, 2004

[6] Jaskowski, Biruk, and Bucon, "Assessing contractor selection criteria weights with fuzzy AHP method application in group decision environment." 2010.

[7] Choo, E.U., Schoner, B, Wedley, W. "Interpretation of criteria weights in multicriteria decision making", 1999.

[8] Abel A. Fernandez, Expert Choice, 1996.

[9] Oyku Alanbay, "ERP selection using expert choice software", 2005. 


\section{Appendix A: Questionnaire Number (1)}

\section{Rate of the relative importance for each criteria}

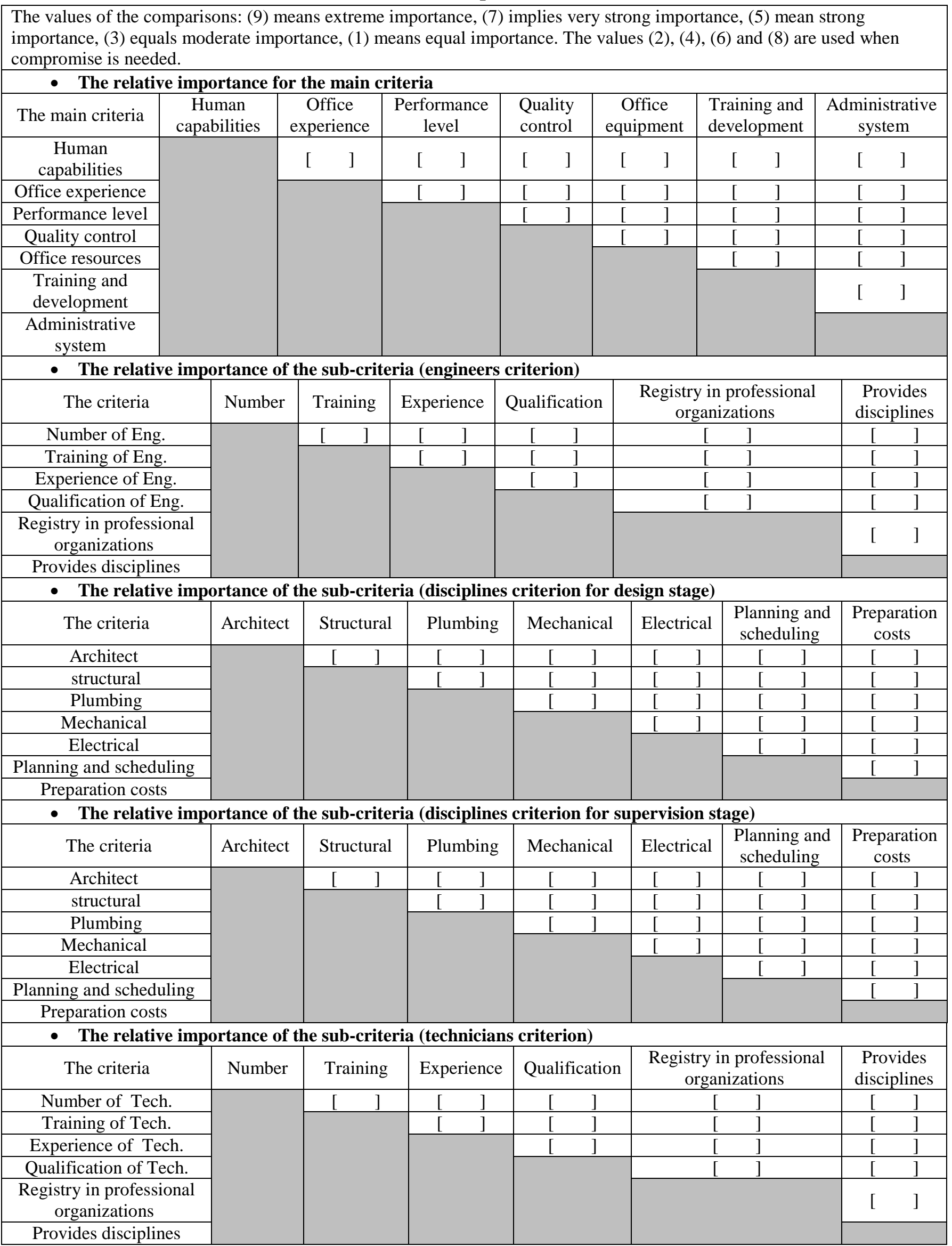




\section{Rate of the relative importance for each criteria}

The values of the comparisons: (9) means extreme importance, (7) implies very strong importance, (5) mean strong importance, (3) equals moderate importance, (1) means equal importance. The values (2), (4), (6) and (8) are used when compromise is needed.

- The relative importance of the sub-criteria (disciplines criterion for design stage)

\begin{tabular}{|c|c|c|c|c|c|c|}
\hline The criteria & $\begin{array}{c}\text { Starter } \\
\text { specifications }\end{array}$ & Painter & $\begin{array}{l}\text { Estimates } \\
\text { specialist }\end{array}$ & $\begin{array}{l}\text { Quantities } \\
\text { specialist }\end{array}$ & $\begin{array}{l}\text { Contracts } \\
\text { specialist }\end{array}$ & $\begin{array}{c}\text { Scheduling project } \\
\text { specialist }\end{array}$ \\
\hline Starter specifications & & {[} & ] & {[} & {[} & ] \\
\hline Painter & & & {[} & ] & {[} & {[} \\
\hline Estimates specialist & & & & {[} & {[} & {[} \\
\hline Quantities specialist & & & & & {[} & ] \\
\hline Contracts specialist & & & & & & $\Gamma$ \\
\hline $\begin{array}{c}\text { Scheduling project } \\
\text { specialist }\end{array}$ & & & & & & \\
\hline
\end{tabular}

- The relative importance of the sub-criteria (disciplines criterion for supervision stage)

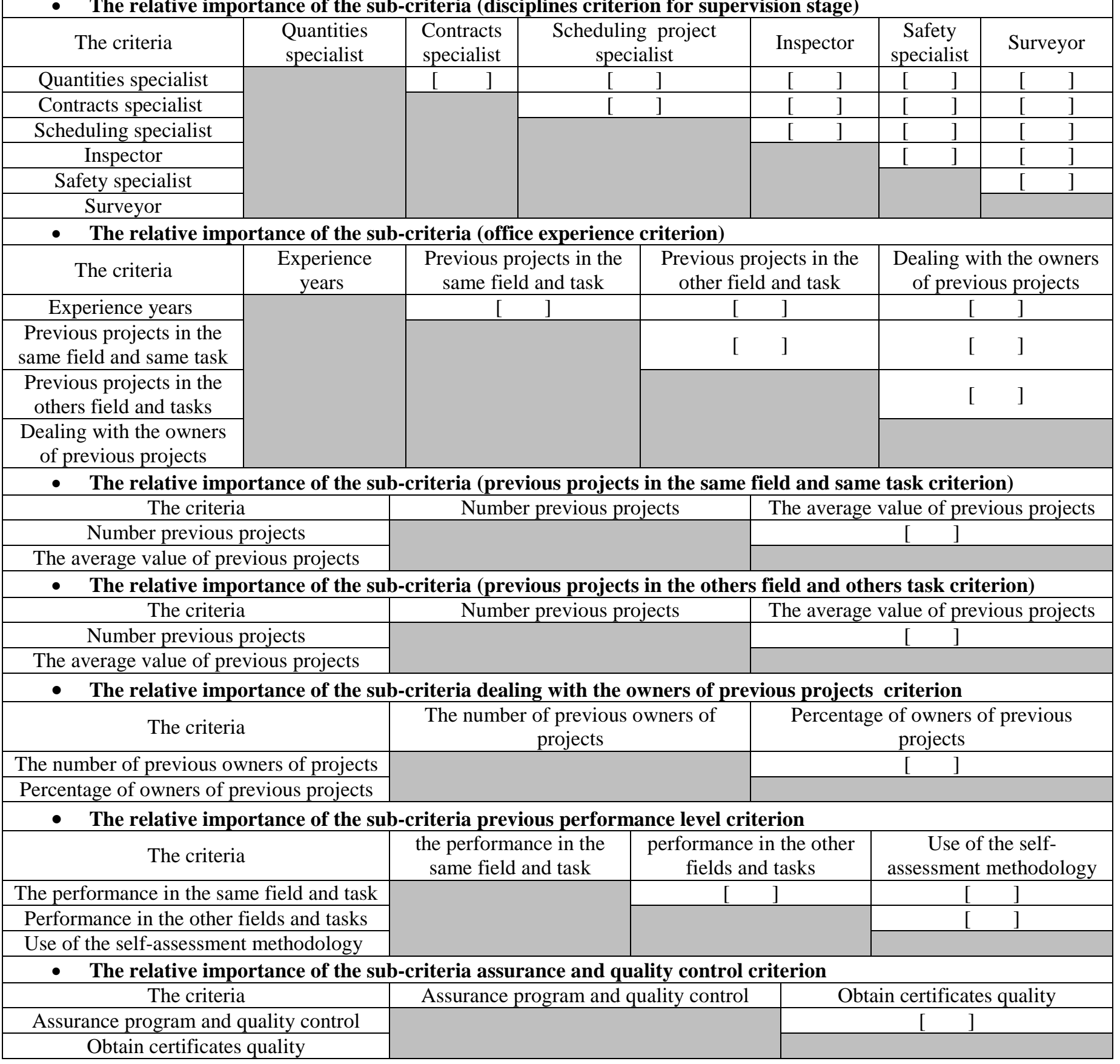




\section{Rate of the relative importance for each criteria}

The values of the comparisons: (9) means extreme importance, (7) implies very strong importance, (5) mean strong importance, (3) equals moderate importance, (1) means equal importance. The values (2), (4), (6) and (8) are used when compromise is needed.

- The relative importance of the sub-criteria (office equipment criterion)

\begin{tabular}{|c|c|c|c|c|c|c|c|}
\hline \multirow{2}{*}{\multicolumn{2}{|c|}{$\begin{array}{l}\text { The criteria } \\
\text { Office area }\end{array}$}} & \multicolumn{2}{|c|}{ Office area } & \multicolumn{2}{|c|}{ Number of branches } & \multicolumn{2}{|c|}{ The use of new technologies } \\
\hline & & & & [ & & {[} & \\
\hline \multicolumn{2}{|c|}{ number of branches } & & & & & {[} & \\
\hline \multicolumn{8}{|c|}{ The use of new technologies } \\
\hline \multicolumn{8}{|c|}{ - The relative importance of the sub-criteria (use of new technologies criterion for design stage) } \\
\hline The criteria & Design & Drawing & Scheduling & $\begin{array}{c}\text { Cost } \\
\text { estimating }\end{array}$ & Man & $\begin{array}{l}\text { ment information } \\
\text { systems }\end{array}$ & $\begin{array}{l}\text { Electronic } \\
\text { archiving }\end{array}$ \\
\hline Design software & & {$[\quad]$} & ] & ] & & ] & ] \\
\hline Drawing & & & & ] & & ] & {[} \\
\hline Scheduling & & & & ] & & ] & ] \\
\hline Cost estimating & & & & & & & {[} \\
\hline $\begin{array}{c}\text { Management information } \\
\text { system }\end{array}$ & & & & & & & {[} \\
\hline Electronic archiving & & & & & & & \\
\hline
\end{tabular}

- The relative importance of the sub-criteria (use of new technologies criterion for supervision stage)

\begin{tabular}{|c|c|c|c|}
\hline The criteria & Scheduling software & Management information system & Electronic archiving \\
\hline Scheduling software & & {[} & {[} \\
\hline $\begin{array}{c}\text { Management information } \\
\text { system }\end{array}$ & & & [ $\quad]$ \\
\hline Electronic archiving & & & \\
\hline
\end{tabular}

- The relative importance of the sub-criteria (training and development criterion)

\begin{tabular}{|c|c|c|c|}
\hline The criteria & Staff training & Conferences participation & Library provides \\
\hline Staff training & & {$[\quad]$} & {[} \\
\cline { 3 - 4 } Conferences participation & & & {[} \\
\hline Library provides & & & \\
\hline
\end{tabular}

- The relative importance of the sub-criteria (library provides criterion)

\begin{tabular}{|c|c|c|c|c|c|}
\hline The criteria & \multicolumn{2}{|c|}{$\begin{array}{c}\text { Copy specifications } \\
\text { standards }\end{array}$} & \multicolumn{2}{|c|}{$\begin{array}{c}\text { Subscribe in specialized periodical } \\
\text { magazines }\end{array}$} & $\begin{array}{l}\text { Providing internet } \\
\text { connection }\end{array}$ \\
\hline $\begin{array}{l}\text { Copy specifications } \\
\text { and standards }\end{array}$ & & & \multicolumn{2}{|c|}{$[\quad]$} & {$[\quad]$} \\
\hline $\begin{array}{l}\text { Subscribe in specialized } \\
\text { periodical magazines }\end{array}$ & & & & & {[} \\
\hline \multicolumn{6}{|l|}{$\begin{array}{l}\text { Providing internet } \\
\text { connection }\end{array}$} \\
\hline \multicolumn{6}{|c|}{ - The relative importance of the sub-criteria (administrative system criterion) } \\
\hline The criteria & $\begin{array}{c}\text { Procedures } \\
\text { manual }\end{array}$ & \multicolumn{2}{|c|}{$\begin{array}{l}\text { Detailed scheduling } \\
\text { for project every }\end{array}$} & $\begin{array}{l}\text { Risk management } \\
\text { program }\end{array}$ & Cost control program \\
\hline Procedures manual & & \multicolumn{2}{|c|}{$[\quad]$} & {[} & {[} \\
\hline $\begin{array}{l}\text { Detailed scheduling for } \\
\text { project every }\end{array}$ & & & & {[} & {$\left[\begin{array}{ll} & \end{array}\right]$} \\
\hline Risk management program & & & & & {[} \\
\hline Cost control program & & & & & \\
\hline
\end{tabular}




\section{Contracting companies / Government institutions / Consulting offices}

\begin{tabular}{|c|c|c|}
\hline No. & Expert & Contact information \\
\hline 1. & Device development and the development of administrative & www.nwd-ly.com \\
\hline 2. & National Company for the drilling and maintenance & www.gecol.ly \\
\hline 3. & Public Works Company- Tripoli & www.ncblibya.com \\
\hline 4. & Railroads Project Execution and Management Board & www.railroads.org.ly \\
\hline 5. & Public Electrical Work Company & www.nricly.com \\
\hline 6. & Implementation Device of Housing Projects & www.hib.org.ly \\
\hline 7. & Africa Engineering and Projects Company & $(+218) 214800574$ \\
\hline 8. & General Construction Company ( Misurata ) & www.ashgal.org.ly \\
\hline 9. & Urban Development Company for Construction and & www.alomrania.com \\
\hline 10. & National Company for housing and utilities contribute & www.nahuco.ly \\
\hline 11. & The General Electricity Company & www.amanplast.com \\
\hline 12. & Interest roads and land -The Ministry of Transportation & http://www.raba.ly \\
\hline 13. & Libyan Urban Planning Association & www.Gb.ly \\
\hline 14. & Interest of public lands & www.amlak.com.ly \\
\hline 15. & The Ministry of Planning - Projects Management Office & www.planning.gov.ly \\
\hline 16. & National Consulting Bureau & www.ucc.ly \\
\hline 17. & Terrace Engineering Consultants & www.terrace.ly \\
\hline 18. & Alsabagco Company for Contracting and Real Estate & www.alsabagco.com \\
\hline 19. & Tarek Al Amal General contracting & www.tagecoly.com \\
\hline 20. & Company of the standard for engineering works & www.almayar.ly \\
\hline 21. & Aracekhoon for Contracting General & www.alatkan.com \\
\hline 22. & Adi for Contracting General & www.majdal.ly \\
\hline 23. & Professional Work Company for General Contracting & www.sarycons.com \\
\hline 24. & Acacos Company for Construction \& Investment & www.immartripoli.com \\
\hline 25. & Libyan Union for Construction Contract & www.aracekhoon.com \\
\hline 26. & Al-ebhar General Construction \& Real Estate & www.pwcgc.com \\
\hline 27. & Golden Bridge Co Contracting and Real Estate & www.alasass.com \\
\hline 28. & Arab Contractors Osman Ahmed Osman \& Co -Libya & wetco.blogspot.com \\
\hline 29. & New Tripoli's Contracting and Real Estate Investment & www.expoarabia.com \\
\hline 30. & FESSATO for Engineering Services (F.E.S.C) & www.fessato.org.ly \\
\hline
\end{tabular}


Appendix C: The obtained weights of relative importance

\begin{tabular}{|c|c|c|c|c|c|}
\hline No. & & & The criteria & \multicolumn{2}{|c|}{ Weights } \\
\hline \multicolumn{4}{|c|}{ Human capabilities } & \multicolumn{2}{|c|}{0.234} \\
\hline \multicolumn{4}{|c|}{ Engineers } & $\mathrm{L}=0.791$ & $\mathrm{G}=0.185$ \\
\hline \multicolumn{4}{|c|}{ Technicians } & $\mathrm{L}=0.209$ & $\mathrm{G}=0.049$ \\
\hline \multicolumn{4}{|r|}{ Sum } & 1 & 0.234 \\
\hline \multicolumn{4}{|c|}{\begin{tabular}{l|l}
$\bullet$ & Number of engineers
\end{tabular}} & \multicolumn{2}{|c|}{0.073} \\
\hline & $\bullet$ & \multicolumn{2}{|c|}{ Experience of engineers } & \multicolumn{2}{|c|}{0.294} \\
\hline & $\bullet$ & \multicolumn{2}{|c|}{ Training of engineers } & \multicolumn{2}{|c|}{0.187} \\
\hline & $\bullet$ & \multicolumn{2}{|c|}{ Qualification of engineers } & \multicolumn{2}{|c|}{0.166} \\
\hline & $\bullet$ & \multicolumn{2}{|c|}{ Registry in organizations } & \multicolumn{2}{|c|}{0.067} \\
\hline & $\bullet$ & \multicolumn{2}{|c|}{ Disciplines: } & \multicolumn{2}{|c|}{0.213} \\
\hline \multicolumn{4}{|r|}{ Sum } & \multicolumn{2}{|c|}{1} \\
\hline & & $\bullet$ & Architect engineer & 0.27 & 0.23 \\
\hline & & $\bullet$ & Structural engineer & 0.247 & 0.251 \\
\hline & & $\bullet$ & Plumbing engineer & 0.115 & 0.079 \\
\hline & & $\bullet$ & Mechanical engineer (HVAC) & 0.096 & 0.077 \\
\hline & & $\bullet$ & Electrical engineer & 0.125 & 0.098 \\
\hline & & $\bullet$ & Planning and scheduling engineer & 0.071 & 0.188 \\
\hline & & $\bullet$ & Preparation costs engineer & 0.076 & 0.077 \\
\hline \multicolumn{4}{|r|}{ Sum } & 1 & 1 \\
\hline & $\bullet$ & & nber of technicians & \multicolumn{2}{|c|}{0.096} \\
\hline & $\bullet$ & & erience of technicians & & \\
\hline & $\bullet$ & & ning of technicians & & \\
\hline & $\bullet$ & & lification of technicians & & \\
\hline & $\bullet$ & & istry in organizations & & \\
\hline & $\bullet$ & & iplines: & & \\
\hline & & & Sum & & \\
\hline & & $\bullet$ & Starter specifications & 0.155 & --- \\
\hline & & $\bullet$ & Painter & 0.239 & --- \\
\hline & & $\bullet$ & Estimates specialist & 0.170 & --- \\
\hline & & $\bullet$ & Quantities specialist & 0.177 & 0.319 \\
\hline & & $\bullet$ & Contracts specialist & 0.131 & 0.153 \\
\hline & & $\bullet$ & Scheduling specialist & 0.127 & 0.135 \\
\hline & & $\bullet$ & Inspector & --- & 0.164 \\
\hline & & $\bullet$ & Safety technicians & --- & 0.098 \\
\hline & & & Sum & 1 & 1 \\
\hline Offic & $\exp$ & rie & & & \\
\hline & & eri & hce years & $\mathrm{L}=0.263$ & $\mathrm{G}=0.047$ \\
\hline & & viol & projects in the same field and the task & $\mathrm{L}=0.527$ & $\mathrm{G}=0.095$ \\
\hline & & iiol & projects in the fields and other tasks & $\mathrm{L}=0.118$ & $\mathrm{G}=0.020$ \\
\hline & & $\operatorname{lin}$ & with the owners of previous projects & $\mathrm{L}=0.092$ & $\mathrm{G}=0.017$ \\
\hline & & & Sum & 1 & 0.179 \\
\hline & $\bullet$ & & nber previous projects in the same field and the task & & \\
\hline & $\bullet$ & & rage of previous projects in the same field and the task & & \\
\hline
\end{tabular}


Appendix C: (Continue) The obtained weights of relative importance

\begin{tabular}{|c|c|c|c|}
\hline No. & The criteria & \multicolumn{2}{|c|}{ Weights } \\
\hline & Sum & \multicolumn{2}{|c|}{1} \\
\hline & • $\quad$ Number previous projects in the fields and other tasks & \multicolumn{2}{|c|}{0.386} \\
\hline & \begin{tabular}{l|l} 
& Average of previous projects in the fields and other tasks
\end{tabular} & \multicolumn{2}{|c|}{0.614} \\
\hline & Sum & \multicolumn{2}{|c|}{1} \\
\hline & \begin{tabular}{l|l}
$\bullet$ & The number of previous owners of projects
\end{tabular} & \multicolumn{2}{|c|}{0.433} \\
\hline & - $\quad$ Percentage of owners of previous projects & \multicolumn{2}{|c|}{0.567} \\
\hline & Sum & \multicolumn{2}{|c|}{1} \\
\hline \multicolumn{2}{|c|}{ Previous performance level } & \multicolumn{2}{|c|}{0.147} \\
\hline & The performance evaluation in the same field and the task & $\mathrm{L}=0.499$ & $\mathrm{G}=0.073$ \\
\hline & The performance evaluation in the other fields and tasks & $\mathrm{L}=0.187$ & $\mathrm{G}=0.028$ \\
\hline & Use of the self-assessment methodology & $\mathrm{L}=0.314$ & $\mathrm{G}=0.046$ \\
\hline \multicolumn{2}{|r|}{ Sum } & 1 & 0.147 \\
\hline \multicolumn{2}{|c|}{ Quality control } & \multicolumn{2}{|c|}{0.163} \\
\hline & Quality control program & $\mathrm{L}=0.463$ & $\mathrm{G}=0.076$ \\
\hline & Quality certificates & $\mathrm{L}=0.537$ & $\mathrm{G}=0.087$ \\
\hline \multicolumn{2}{|r|}{ Sum } & 1 & 0.163 \\
\hline \multicolumn{2}{|c|}{ Office equipment } & \multicolumn{2}{|c|}{0.049} \\
\hline & Office area & $\mathrm{L}=0.163$ & $\mathrm{G}=0.008$ \\
\hline & Number consultant office the branches & $\mathrm{L}=0.207$ & $\mathrm{G}=0.010$ \\
\hline & The use of new technologies: & $\mathrm{L}=0.630$ & $\mathrm{G}=0.031$ \\
\hline & Sum & 1 & 0.049 \\
\hline & - $\quad$ Design software’s & 0.295 & --- \\
\hline & \begin{tabular}{l|l} 
& Drawing programs \\
\end{tabular} & 0.260 & --- \\
\hline & \begin{tabular}{l|l}
$\bullet$ & Cost estimating software's
\end{tabular} & 0.103 & --- \\
\hline & \begin{tabular}{l|l}
$\bullet$ & Scheduling programs
\end{tabular} & 0.131 & 0.399 \\
\hline & \begin{tabular}{l|l}
$\bullet$ & Management information systems
\end{tabular} & 0.121 & 0.328 \\
\hline & \begin{tabular}{l|l}
$\bullet$ & Electronic archiving
\end{tabular} & 0.090 & 0.272 \\
\hline & Sum & 1 & 1 \\
\hline Train & ng and development & & \\
\hline & Staff training in their field of specialization & $\mathrm{L}=0.559$ & $\mathrm{G}=0.072$ \\
\hline & The participate in the scientific conferences & $\mathrm{L}=0.180$ & $\mathrm{G}=0.023$ \\
\hline & Presence integrated library contains the following: & $\mathrm{L}=0.261$ & $\mathrm{G}=0.034$ \\
\hline & Sum & 1 & 0.129 \\
\hline & \begin{tabular}{l|l} 
& New copies of specifications and standards
\end{tabular} & & \\
\hline & \begin{tabular}{l|l} 
& Subscribe in specialized periodical magazines
\end{tabular} & & \\
\hline & \begin{tabular}{l|l}
$\bullet$ & Providing internet connection
\end{tabular} & & \\
\hline & Sum & & \\
\hline Admi & istrative system & & \\
\hline & Procedures manual & $\mathrm{L}=0.341$ & $\mathrm{G}=0.034$ \\
\hline & Projects scheduling system & $\mathrm{L}=0.360$ & $\mathrm{G}=0.036$ \\
\hline & Risk management program & $\mathrm{L}=0.134$ & $\mathrm{G}=0.013$ \\
\hline & Cost management program & $\mathrm{L}=0.165$ & $\mathrm{G}=0.016$ \\
\hline & Sum & 1 & 0.099 \\
\hline
\end{tabular}


- The average number of engineers

Give a value from 1-100

-The average experience years

\begin{tabular}{|l|l|l|l|l|l|l|l|}
$\square$ & 5 & $\square$ & 10 & $\square$ & 15 & $\square$ & $>20$ years
\end{tabular}

-The average number of months training

\begin{tabular}{l|l|l|l|l|l|l|l|}
$\square$ & 5 & $\square$ & 10 & $\square$ & 15 & $\square$ & 20
\end{tabular}

-The average percentage of registered engineers in specialized professional organizations

\begin{tabular}{l|l|l|l|l|l|l|l}
$\square$ & $25 \%$ & $\square$ & $50 \%$ & $\square$ & $75 \%$ & $\square$ & $100 \%$
\end{tabular}

- The ratio the certificate holders (Master)

\begin{tabular}{|l|l|l|l|l|l|l|l}
\hline$\square$ & $25 \%$ & $\square$ & $50 \%$ & $\square$ & $75 \%$ & $\square$ & $100 \%$
\end{tabular}

-The ratio the certificate holders (Bachelor)

\begin{tabular}{|l|l|l|l|l|l|l|l}
$\square$ & $25 \%$ & $\square$ & $50 \%$ & $\square$ & $75 \%$ & $\square$ & $100 \%$ \\
\hline
\end{tabular}

- The average number of technicians

Give a value from 1-100

-The average experience years

\begin{tabular}{|l|l|l|l|l|l|l|l|}
$\square$ & 5 & $\square$ & 10 & $\square$ & 15 & $\square$ & $>20$ years \\
\hline
\end{tabular}

-The average number of months training

\begin{tabular}{l|l|l|l|l|l|l|l|}
$\square$ & 5 months & $\square$ & 10 months & $\square$ & 15 month & $\square$ & 20 month
\end{tabular}

-The average percentage of registered engineers in specialized professional organizations

\begin{tabular}{l|l|l|l|l|l|l|l}
$\square$ & $25 \%$ & $\square$ & $50 \%$ & $\square$ & $75 \%$ & $\square$ & $100 \%$ \\
\hline
\end{tabular}

-The ratio the certificate holders (Diploma)

\begin{tabular}{|l|l|l|l|l|l|l|l}
\hline$\square$ & $25 \%$ & $\square$ & $50 \%$ & $\square$ & $75 \%$ & $\square$ & $100 \%$ \\
\hline
\end{tabular}

-The average of experience years for the office

\begin{tabular}{|l|l|l|l|l|l|l|l|}
$\square$ & 10 & $\square$ & 15 & $\square$ & 20 & $\square$ & 25
\end{tabular}

- The average number of previous projects in the same field and the same task

\begin{tabular}{l|l|l|l|l|l|l|l}
$\square$ & 15 & $\square$ & 20 & $\square$ & 25 & $\square$ & 30
\end{tabular}

-The average values the previous projects in the same field and the same task

\begin{tabular}{|l|l|l|l|l|l|l|l|}
$\square$ & 200 & $\square$ & 400 & $\square$ & 600 & $\square$ & 800
\end{tabular}

-The average number of previous projects in the same field (building) and the same task (design)

\begin{tabular}{|l|l|l|l|l|l|l|l}
$\square$ & 25 & $\square$ & 50 & $\square$ & 75 & $\square$ & 100
\end{tabular}

-The average number of previous projects in the other fields and others tasks

\begin{tabular}{|l|l|l|l|l|l|l|l|}
$\square$ & 3 & $\square$ & 6 & $\square$ & 9 & $\square$ & 12
\end{tabular}

-The average values the previous projects in the other fields and tasks, construction cost, (LYD)

\begin{tabular}{|l|l|l|l|l|l|l|l}
$\square$ & 200 & $\square$ & 300 & $\square$ & 400 & $\square$ & 500
\end{tabular}

- The average number of previous projects in the fields and other tasks

\begin{tabular}{|l|l|l|l|l|l|l|l}
$\square$ & 25 & $\square$ & 50 & $\square$ & 75 & $\square$ & 100
\end{tabular}

-The average number of previous owners of projects who have been dealing with them

\begin{tabular}{|l|l|l|l|l|l|l|l|}
$\square$ & 5 & $\square$ & 10 & $\square$ & 15 & $\square$ & 20
\end{tabular}

- The average percentage of owners repetition who has been dealing with them

\begin{tabular}{l|l|l|l|l|l|l|l}
$\square$ & $20 \%$ & $\square$ & $40 \%$ & $\square$ & $60 \%$ & $\square$ & $80 \%$ \\
\hline
\end{tabular}

-The average office area

\begin{tabular}{|l|l|l|l|l|l|l|l}
$\square$ & $200 \mathrm{~m}^{2}$ & $\square$ & $300 \mathrm{~m}^{2}$ & $\square$ & $400 \mathrm{~m}^{2}$ & $\square$ & $500 \mathrm{~m}^{2}$
\end{tabular}

-The average number of consultant office the branches

\begin{tabular}{|l|l|l|l|l|l|l|l|}
$\square$ & 1 & $\square$ & 2 & $\square$ & 3 & $\square$ & 4 \\
\hline
\end{tabular}

-The average of the training months provided by the office for staff

\begin{tabular}{l|l|l|l|l|l|l|l|}
\hline & 0.5 month & $\square$ & 1 month & $\square$ & 1.5 month & $\square$ & 2 month
\end{tabular}

-The average posts in scientific conferences and seminars

\begin{tabular}{l|l|l|l|l|l|l|l|}
$\square$ & 2 & $\square$ & 4 & $\square$ & 6 & $\square$ & 8
\end{tabular}




\section{Basic information for the office}

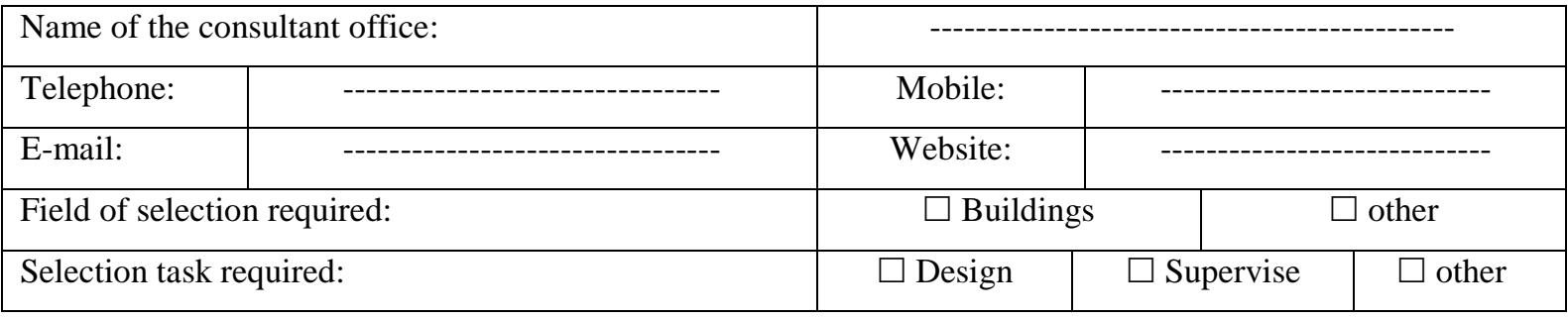

Information about all the engineers in the office

\begin{tabular}{|c|c|c|c|c|c|c|c|}
\hline \multirow[b]{2}{*}{ No. } & \multirow[b]{2}{*}{ Name } & \multirow{2}{*}{$\begin{array}{c}\text { Qualification } \\
\text { scientific }\end{array}$} & \multirow{2}{*}{$\begin{array}{c}\text { Graduation } \\
\text { year }\end{array}$} & \multicolumn{2}{|c|}{ Training period ( month) } & \multirow[b]{2}{*}{ Specialty } & \multirow{2}{*}{$\begin{array}{l}\text { Professiona } \\
\text { association } \\
\text { membership }\end{array}$} \\
\hline & & & & $\begin{array}{c}\text { Since } \\
\text { graduation }\end{array}$ & $\begin{array}{c}\text { By working in } \\
\text { the office }\end{array}$ & & \\
\hline 1. & --- & --- & --- & --- & --- & --- & $\square$ \\
\hline 2. & --- & --- & --- & --- & --- & --- & $\square$ \\
\hline n. & --- & --- & --- & --- & --- & --- & $\square$ \\
\hline
\end{tabular}

Information about all the technicians in the office

\begin{tabular}{|c|c|c|c|c|c|c|c|}
\hline \multirow[b]{2}{*}{ No. } & \multirow[b]{2}{*}{ Name } & \multirow{2}{*}{$\begin{array}{c}\text { Qualification } \\
\text { scientific }\end{array}$} & \multirow{2}{*}{$\begin{array}{c}\text { Graduation } \\
\text { year }\end{array}$} & \multicolumn{2}{|c|}{ Training period ( month) } & \multirow[b]{2}{*}{ Specialty } & \multirow{2}{*}{$\begin{array}{l}\text { Professional } \\
\text { association } \\
\text { membership }\end{array}$} \\
\hline & & & & $\begin{array}{c}\text { Since } \\
\text { graduation }\end{array}$ & $\begin{array}{c}\text { By working in } \\
\text { the office }\end{array}$ & & \\
\hline 1. & --- & --- & --- & --- & --- & --- & $\square$ \\
\hline 2. & --- & --- & --- & --- & --- & --- & $\square$ \\
\hline $\mathrm{n}$. & --- & --- & --- & --- & --- & --- & $\square$ \\
\hline
\end{tabular}

Information about the projects implemented out by the office

\begin{tabular}{|c|c|c|c|c|c|c|c|}
\hline No. & $\begin{array}{c}\text { Type of } \\
\text { project }\end{array}$ & Owner & $\begin{array}{c}\text { The cost of } \\
\text { implementing } \\
\text { the project }\end{array}$ & $\begin{array}{c}\text { Task the } \\
\text { office in the } \\
\text { project }\end{array}$ & $\begin{array}{c}\text { Project } \\
\text { field }\end{array}$ & $\begin{array}{c}\text { Date end the } \\
\text { contract }\end{array}$ & $\begin{array}{c}\text { Assessment the } \\
\text { performance of } \\
\text { the office }\end{array}$ \\
\hline 1. & --- & --- & --- & --- & --- & --- & -- \\
\hline 2. & --- & --- & --- & --- & --- & --- & -- \\
\hline n. & --- & --- & --- & --- & --- & -- & - \\
\hline
\end{tabular}

\section{General data for the office}

\begin{tabular}{|c|l|c|}
\hline $\mathbf{( 4 )}$ & 1st project start date & $------/------/-----$ \\
\hline $\mathbf{( 5 )}$ & The number of previous owners of projects & {[} \\
\hline $\mathbf{( 6 )}$ & Percent of client repetition & {[} \\
\hline $\mathbf{( 7 )}$ & Total office area $\left(\mathrm{m}^{2}\right)$ & {[} \\
\hline $\mathbf{( 8 )}$ & Number consultant office the branches & {[} \\
\hline $\mathbf{( 9 )}$ & Number of posts in scientific conferences and symposia & {[} \\
\hline
\end{tabular}




\section{Technical expertise to the office}

\begin{tabular}{|c|c|c|c|c|c|}
\hline \multicolumn{6}{|c|}{$\begin{array}{l}\text { (10) Extent to use the office for the following programs: } \\
\text { - The used program: gives a grade } 100 \square\end{array}$} \\
\hline \multicolumn{6}{|c|}{ - The unused program: gives a degree zero $₫$} \\
\hline (a) & Quality certificate & $\square$ & Yes & $\square$ & No \\
\hline (b) & Design software’s & $\square$ & Yes & $\square$ & No \\
\hline (c) & Drawing programs & $\square$ & Yes & $\square$ & No \\
\hline (d) & Cost estimating software's & $\square$ & Yes & $\square$ & No \\
\hline (e) & Scheduling software's & $\square$ & Yes & $\square$ & No \\
\hline (f) & Management information system (MIS) & $\square$ & Yes & $\square$ & No \\
\hline (g) & Electronic archiving & $\square$ & Yes & $\square$ & No \\
\hline (h) & Internet connection & $\square$ & Yes & $\square$ & No \\
\hline \multicolumn{6}{|c|}{ (11) Assessment use the following programs in the office, between (0-100): } \\
\hline No. & The program & \multicolumn{4}{|c|}{ Grade } \\
\hline (a) & Performance assessment self-methodology & \multicolumn{4}{|c|}{$[\quad]$} \\
\hline (b) & Program assurance and quality control & \multicolumn{4}{|c|}{$\left[\begin{array}{ll} & \end{array}\right]$} \\
\hline (c) & Copies of specifications and standards & \multicolumn{4}{|c|}{$\left[\begin{array}{ll} & \end{array}\right]$} \\
\hline (d) & Participate in specialized magazines and periodicals. & \multicolumn{4}{|c|}{ [ ] $]$} \\
\hline (e) & Procedures manual & \multicolumn{4}{|c|}{$[\quad]$} \\
\hline (f) & $\begin{array}{l}\text { - Prepare a detailed schedule for each project } \\
\text { - Supervision and periodic follow the stages of completion of the project }\end{array}$ & \multicolumn{4}{|c|}{$\left[\begin{array}{ll} & ]\end{array}\right]$} \\
\hline (g) & costs management system & \multicolumn{4}{|c|}{$[\quad]$} \\
\hline (h) & Risk management program & \multicolumn{4}{|c|}{ [ $]$} \\
\hline
\end{tabular}

